\title{
Water masses and circulation between the eastern Algerian Basin and the Strait of Sicily in October 1996
}

\author{
Reiner ONKEN*, Jürgen SELLSCHOPP \\ SACLANT Undersea Research Centre, viale San Bartolomeo, 400, 19138 La Spezia, Italy
}

Received 21 February 2000; revised 21 August 2000; accepted 25 August 2000

\begin{abstract}
The investigation is based on data collected between the eastern Algerian Basin and the Strait of Sicily and in the southern Tyrrhenian Sea. The major pathways of water masses are identified by the core method and geostrophic currents are derived from the objectively analysed density field. Between the Sardinia Channel and the Strait of Sicily, the large-scale circulation of Modified Atlantic Water and Winter Intermediate Water is found to be cyclonic. Inflow into the gyre occurs via the Sardinia Channel by means of a boundary current attached to the Algerian coast, and from the northern Tyrrhenian. The outflow is accomplished via the Strait of Sicily and to the Tyrrhenian. The Levantine intermediate water flow resembles that of Modified Atlantic Water/Winter Intermediate Water in the southern Tyrrhenian, but it is opposed in the Strait of Sicily and off Tunisia. Outflow to the Algerian Basin occurs south of Sardinia. In the eastern Algerian Basin the flow direction of all water masses is eastward close to the Algerian shelf. Farther offshore, Modified Atlantic Water flows mainly southwest whereas the Levantine Intermediate Water is opposed to that supporting northward transport along the Sardinian shelf. The large-scale flow of all water masses is perturbed by mesoscale eddies. The impact of topographic obstacles is investigated. (C) 2001 Ifremer/CNRS/IRD/Éditions scientifiques et médicales Elsevier SAS
\end{abstract}

Résumé - Masses d'eau et circulation entre le bassin algérien et le détroit de Sicile en octobre 1996. Cette étude est basée sur l'utilisation de données océanographiques collectées entre le bassin algérien et le détroit de Sicile et dans la partie sud de la mer Tyrrhénienne. Entre le canal de Sardaigne et le détroit de Sicile, la circulation à grande échelle des eaux modifiées de l'Atlantique et des eaux intermédiaires d'hiver est identifiée comme cyclonique. L'apport en flux dans la rotation se fait principalement par le canal de Sardaigne, grâce à un courant intense le long de la côte algérienne et le long de la mer Tyrrhénienne septentrionale. L'écoulement s'effectue par le détroit de Sicile et vers la mer Tyrrhénienne. Le flux des eaux intermédiaires du Levant ressemble à celui de l'ensemble eau modifiée de l'Atlantique/eau intermédiaire d'hiver dans la partie sud de la mer Tyrrhénienne. Dans le détroit de Sicile et près des côtes de Tunisie, le flux de l'eau intermédiaire du Levant est opposé ; l'écoulement vers le bassin algérien s'effectue au sud de la Sardaigne. Dans la partie est du bassin algérien, toutes les masses d'eau sont dirigées vers l'est, près du plateau algérien. Au large et à l'ouest de la Sardaigne, l'eau modifiée de l'Atlantique s'écoule principalement vers le sud ouest alors que l'eau intermédiaire du Levant s'écoule, à l'opposé, vers le nord le long du plateau de la Sardaigne. Le flux à grande échelle de toutes les masses d'eau est perturbé par les tourbillons. L'impact des obstacles topographiques est étudié. (C) 2001 Ifremer/CNRS/IRD/Éditions scientifiques et médicales Elsevier SAS

\section{Mediterranean / Algerian Basin / water masses}

Méditerranée / bassin algérien / masses d'eau

* Correspondence and reprints: fax: +390187 527331.

E-mail address: onken@saclantc.nato.int (R. ONKEN).

(C) 2001 Ifremer/CNRS/IRD/Éditions scientifiques et médicales Elsevier SAS. Tous droits réservés 


\section{INTRODUCTION}

In October 1996, a hydrographic survey was conducted by the NATO research vessel Alliance. The survey area (figure 1) is centred approximately between Sardinia, Sicily and Tunisia, and extends into the western Algerian Basin, the southern Tyrrhenian and the western part of the Strait of Sicily. The campaign was motivated by the fact that this area is one of the less well understood of the Mediterranean, although it is a crossroads for the water masses in the western Mediterranean, namely Modified Atlantic Water (MAW), Winter Intermediate Water (WIW), Levantine Intermediate Water (LIW), and the deep Water masses. Because the majority of the measurements were limited to depths shallower than about $1000 \mathrm{~m}$, the objective of this study is to investigate the distribution of MAW, WIW, and LIW and to provide a consistent circulation pattern.

MAW originates from the inflow of Atlantic water through the Strait of Gibraltar. It is the surface water of the Mediterranean and occupies the upper 100-200 m depth range. Due to evaporation and mixing, its salinity progressively increases along its path; however, because evaporation affects mainly the mixed-layer salinity, MAW can be traced by a subsurface salinity minimum. The inflow of MAW into the survey area is from the west by means of the Algerian Current. According to older literature, the flow separates at the entrance of the Sardinia Channel into a northward branch along the west coast of Sardinia and a southern branch heading east towards the Strait of Sicily. By contrast, more recent observations and models suggest a northward flow along the west coast of Sardinia only in winter. The major part of MAW, roughly two thirds of the Sardinia Channel inflow, leaves the survey area via the Strait of Sicily towards the Eastern Mediterranean (Bethoux, 1980). The rest proceeds into the Tyrrhenian, and partly recirculates cyclonically towards the Sardinia Channel. For further information on the circulation in the Tyrrhenian, the reader is referred to the review of Astraldi and Gasparini (1994).

WIW is formed in the Western Mediterranean by surface cooling of MAW during winter in the Ligurian Sea and off the Catalan Coast (Lacombe and Tchernia, 1960; Salat and Font, 1987). After restratification of the near surface layers, WIW becomes insulated and can be traced by means of a temperature minimum located between about 100 and $200 \mathrm{~m}$ depth. Up till now, the circulation of WIW has been investigated only in the Algerian Basin, and there is evidence that it follows approximately the same flow paths as the overlying MAW (Millot, 1999).

LIW originates from convection in the Eastern Mediterranean, and can be identified by means of a salinity maximum at intermediate depths. From the source region, LIW spreads westward and spills over the sills of the Strait of Sicily. Its fate is then controversial; Wüst

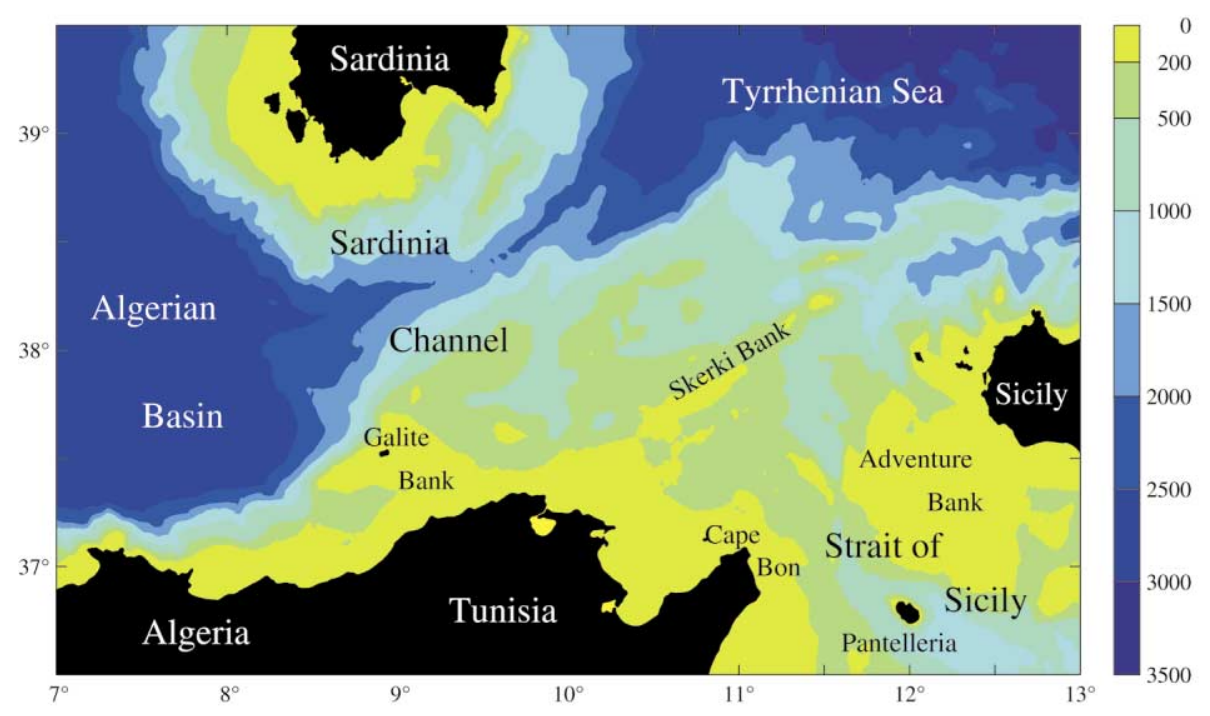

Figure 1. Bathymetry and geographic names of the survey area. 
(1961) suggested one part to turn north around Sicily, and a westward branch to continue straight ahead to the Sardinia Channel. Evidence for this was also found by Garzoli and Maillard (1979) and is reproduced by some recent numerical models. By contrast, the latter branch was not verified by Ovchinnikov (1966). According to his calculations, the LIW proceeds to the southern Tyrrhenian and then bifurcates with one part joining the basin-scale cyclonic gyre, and another one performing a shorter cyclonic loop. Both reunite in the southwestern Tyrrhenian and leave the basin via a concentrated flow around the southern tip of Sardinia. Later, elements of essentially the same pattern were also identified by other authors.

The above review has shown that there exists detailed knowledge of the circulation in the survey area, but many findings are contradictory. The obvious reason for this is that the knowledge was accumulated from many surveys, none of which was synoptic with respect to the entire region. A possible way out of this situation could be to take a mean over all observations and create a 'climatology', however, this would smooth or even delete the majority of mesoscale features and fabricate a situation which never exists. Therefore, the major objective of this paper is to present a synoptic picture of the distribution and circulation of water masses.

\section{MATERIAL AND METHODS}

The oceanographic survey covered the period 19-31 October 1996. The data discussed here consists of casts from CTD (conductivity-temperature-depth), XCTD (expendable CTD), and XBT (expendable bathythermograph). In addition, we shall refer to currents measured by ship borne ADCP (acoustic doppler current profiler), and AVHRR (advanced very high-resolution radiometer) satellite data of sea surface temperature. The casts were arranged mostly on parallel meridional tracks spaced approximately $36.5 \mathrm{~km}$ apart (figure 2), the nominal along-track spacing between individual casts was approximately $15.7 \mathrm{~km}$. In deep water, the majority of CTD casts was limited to about $1000 \mathrm{~m} \mathrm{depth}$, the maximum vertical extent of XCTDs was around $1000 \mathrm{~m}$, that of XBTs close to $750 \mathrm{~m}$.

Objective analysis (Carter and Robinson, 1987) is applied throughout, whenever any scalar variable is to be displayed on horizontal or quasi-horizontal surfaces. The employed correlation scale of $40 \mathrm{~km}$ is a compromise between the desire to resolve mesoscale features on the one hand and taking account of the track spacing on the other hand. The observational error $\varepsilon$ is defined to be $10 \%$ of the standard deviation of the observations.
Figure 2. Positions of CTD (๑), $\mathrm{XCTD}(+)$, and XBT $(*)$ measurements. Lines indicate the $500 \mathrm{~m}$ and $2500 \mathrm{~m}$ depth contours.

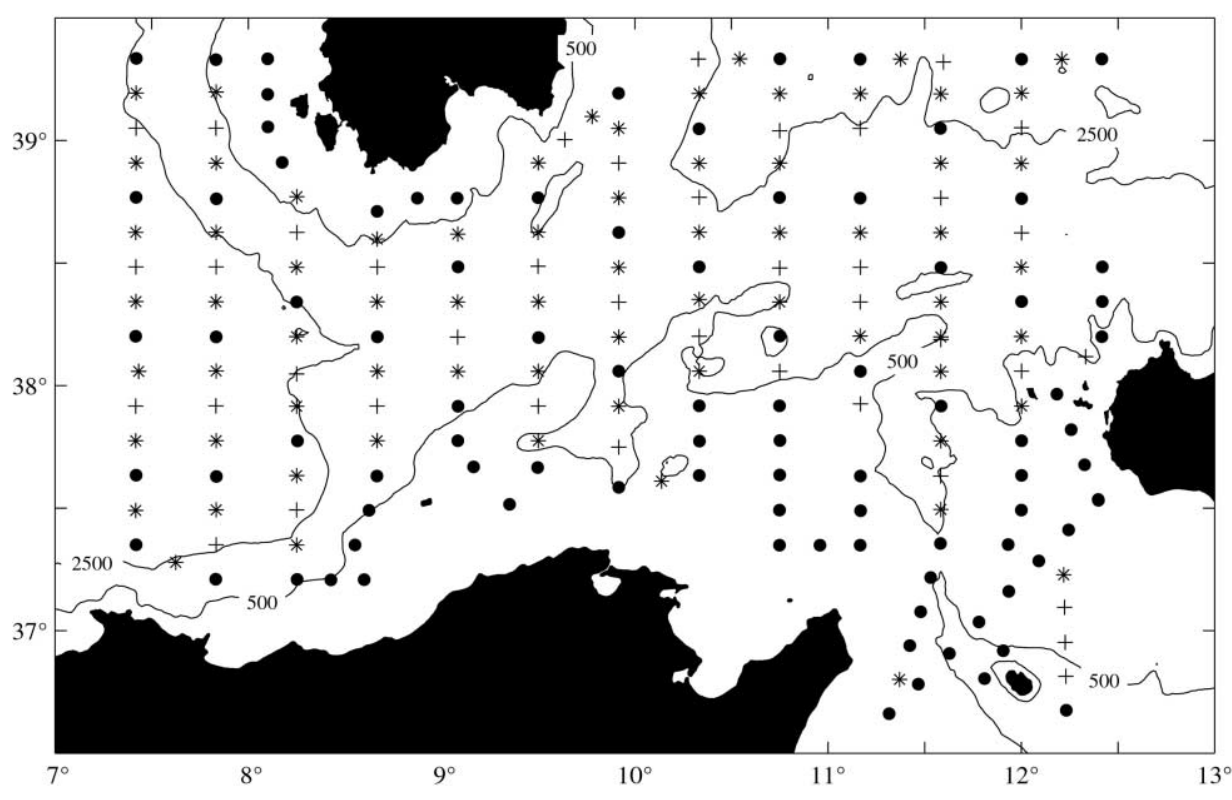




\section{RESULTS}

\subsection{Modified Atlantic Water}

In order to visualize the horizontal distribution of MAW, CTD and XCTD profiles were scanned for a subsurface salinity minimum and subsequently, $S\left(S_{\min }\right)$ and $p\left(S_{\min }\right)$, the salinity and the pressure of the minimum, were objectively analysed. Over the major part of survey area, $p\left(S_{\min }\right)$ lies between about 30 and 70 dbar (figure 3, bottom). Larger values of up to $100 \mathrm{dbar}$ and more are found in a $30 \mathrm{~km}$ wide stripe extending along the Algerian/Tunisian coast up to Cape Bon. Provided that low $S\left(S_{\min }\right)$ values correspond to 'young' MAW, figure 3 reveals that MAW enters the survey area from the west close to the Algerian coast. At about $11^{\circ} \mathrm{E}$, the low salinity vein splits in two branches. One turns south around Cape Bon and the other is directed northeast towards the Tyrrhenian. Here, according to the shape of the 37.7 and 37.8 isohalines, there is indication that MAW partially recirculates to the west. The rather high

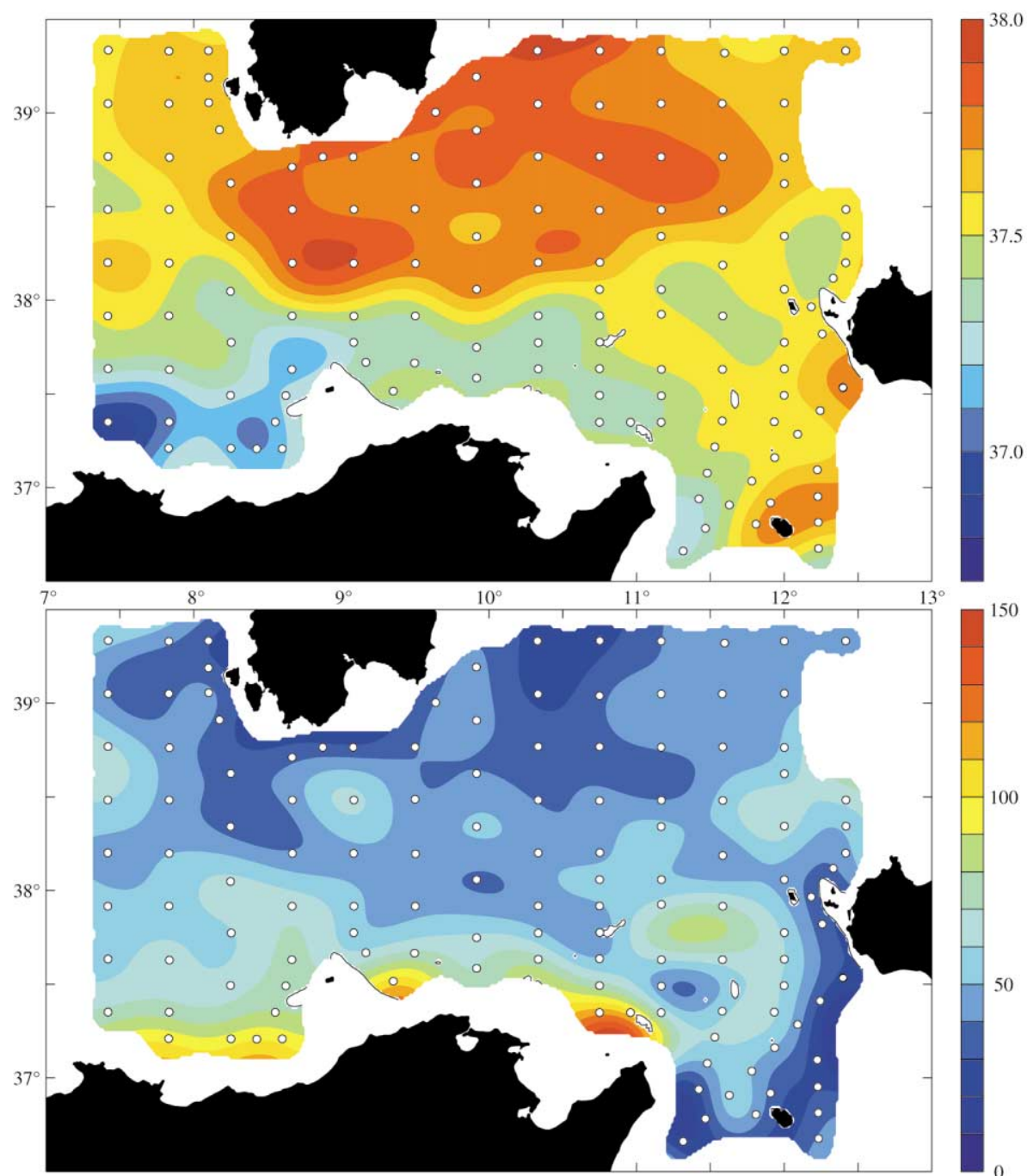

Figure 3. Objectively analysed salinity $S\left(S_{\min }\right)$ (top) and pressure $p\left(S_{\min }\right)$ in decibar (bottom) of the MAW salinity minimum. White dots indicate stations where a subsurface salinity minimum was found. Black solid lines denote the intersection of the $p\left(S_{\min }\right)$ surface with the bathymetry $H$. Areas where the root mean square error of the analysed fields is greater than $2 \varepsilon$ or $p\left(S_{\min }\right)>H$ are left white. 
$S\left(S_{\min }\right)$ values south and east of Sardinia exceeding 37.7 suggest this MAW to be rather old, it probably performed a basin-scale cyclonic loop in the Tyrrhenian and returns to the Sardinia Channel. Other patches of high $S\left(S_{\min }\right)$ are located between Sicily and Pantelleria.

As the core method allows one to make only limited conclusions on the predominant pathways of water masses, the geostrophic currents averaged over the MAW vertical range were calculated from the objectively analysed density field. WIW is the water mass next to MAW, hence the lower MAW boundary was selected as $0.5\left[p\left(S_{\min }\right)+p\left(T_{\min }\right)\right]$, where $p\left(T_{\min }\right)$ is the pressure of the WIW temperature minimum (see below). Although the geostrophic velocity (figure 4) is perturbed by mesoscale eddies, it is possible to identify larger-scale flow paths. The dominant feature is an intense boundary current heading eastward along the Algerian/Tunisian coast and then turning south into the Strait of Sicily. Maximum speeds are reaching almost $60 \mathrm{~cm} \mathrm{~s}^{-1}$ east of Cape Bon. West of the Sardinia Channel, this current apparently is the eastward continuation of the Algerian Current, but in the channel, it is in addition fed by another flow coming from west of Sardinia. At about $11^{\circ} \mathrm{E}$, part of the current splits off generating a branch directed east. When approaching Sicily, this branch separates again into southward flow and a northern branch towards the Eastern Tyrrhenian. Part of the latter recirculates to the west forming a cell of about $100 \mathrm{~km}$ size between Sicily and Sardinia. At its northern flank, this cell is also fed by MAW coming from the central Tyrrhenian. In the Sardinia Channel, the flow is eastward just off the Sardinian coast and a band of westward flow is located about 30' farther south. It appears that this westward flow recirculates to the east by means of a cyclone/anticyclone pair. Hence, there is no visible westward return flow across the Sardinia Channel. Two outstanding features, which have not yet been addressed, are the anticyclonic eddies located over the Adventure Bank and east of Sardinia, to be denoted as the Adventure Bank anticyclone and the Sardinia anticyclone. The latter appears to entrain MAW from the cyclonic recirculation mentioned before and the major part of MAW flowing eastward off the Sardinian South Coast. The Adventure Bank anticyclone is apparently fed by the eastward branch immediately after flow splitting at $11^{\circ} \mathrm{E}$. At its southwestern flank, this eddy contributes to the southward boundary current off Tunisia.

For validation of the geostrophic flow pattern, we have provided ADCP measurements of the near surface velocity field. Without going too much into detail, figure 5 resembles figure 4, except for the pattern west of Sardinia and the anticyclonic meander of the Algerian Current at about $\left(8^{\circ} \mathrm{W}, 38^{\circ} \mathrm{N}\right)$, which is not reflected by the ADCP measurements. Probably, these differences are due to the different ranges of vertical averaging (fixed range for ADCP, variable lower boundary for the geostrophic currents). In addition, the ADCP currents are generally
Figure 4. MAW mean geostrophic velocity assuming a level of no motion at 1000 dbar. For definition of the MAW layer see text. Only every fourth vector was plotted.

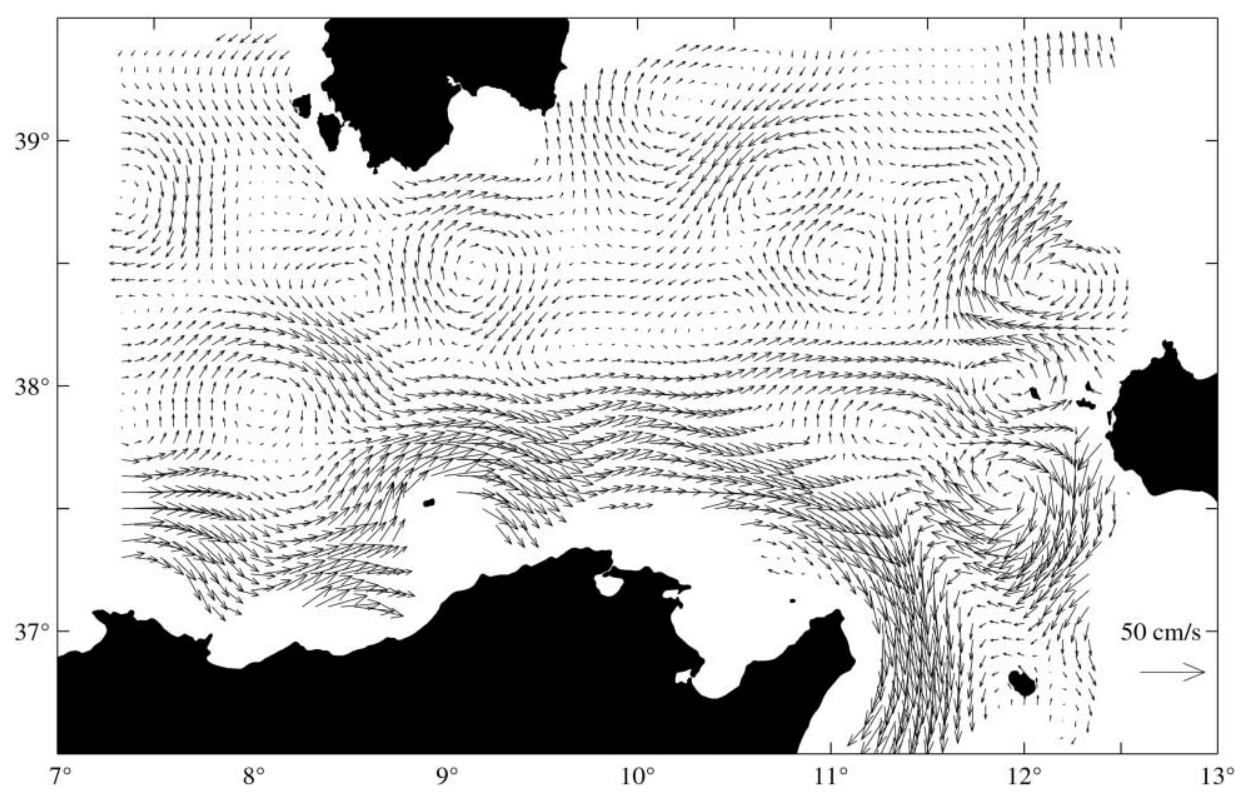




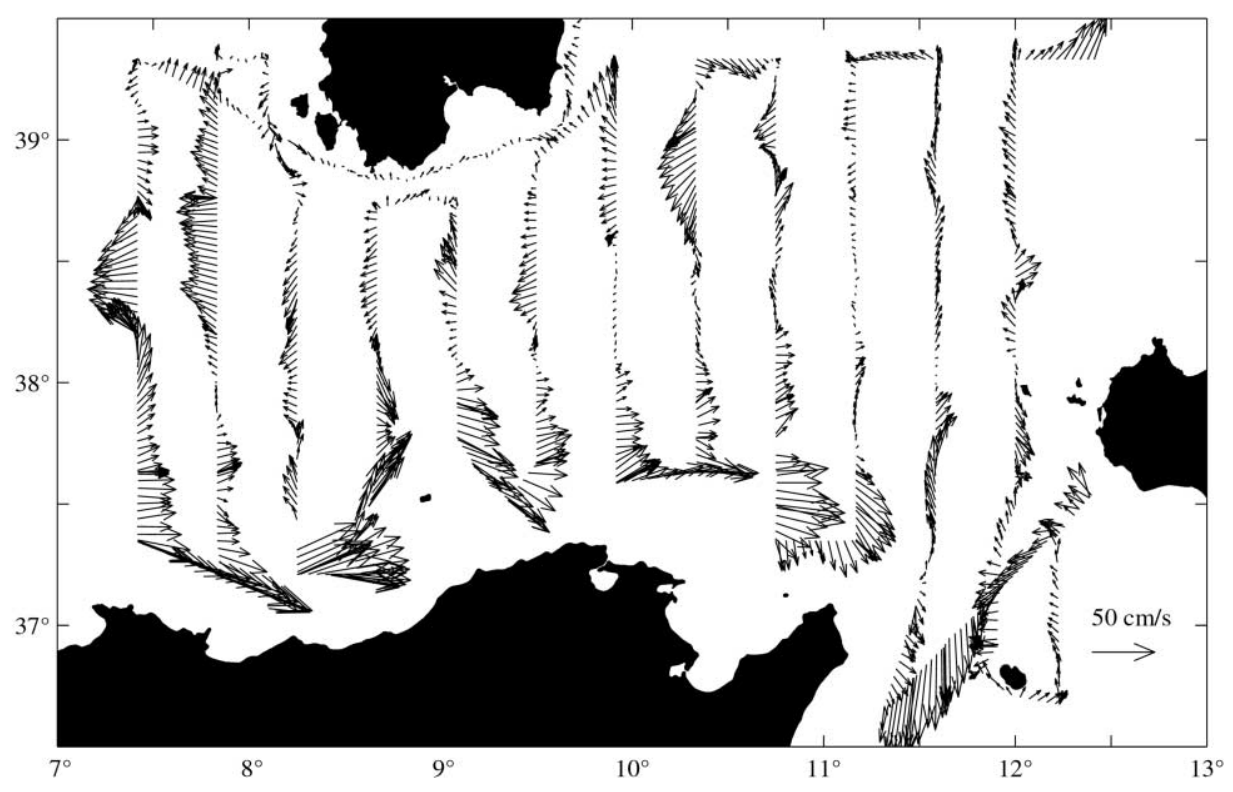

Figure 5. Currents directly measured from ship-borne ADCP, averaged over the vertical range $18-98 \mathrm{~m}$. Each vector represents a 10 min ensemble average. stronger than the geostrophic, which is obviously caused by the smoothing of the objective analysis of the density field.

Further validation may be obtained from a satellite image of sea surface temperature (figure 6). The eye-catching feature is the northwest/southeast oriented front which extends over the entire survey area, separating warm water $\left(T>18^{\circ} \mathrm{C}\right)$ in the south from colder water in the north. The position of the front closely resembles that of the 37.52 isohaline of figure 3, hence the front apparently forms the boundary between new MAW from the Algerian Basin and recirculated MAW. A warm tongue directed towards the Tyrrhenian clearly indicates the flow separation at $11^{\circ} \mathrm{E}$. The Adventure Bank anticyclone appears as a warm patch, and the link between the eddy and the MAW flow around Cape Bon is visible by means of a frontal meander. A warm filament centred at about $\left(10^{\circ} \mathrm{E}, 39^{\circ} \mathrm{N}\right)$ matches the azimuthal flow of the Sardinia anticyclone.

The geostrophic circulation has revealed several features, which were expected from previous knowledge; other features appear to be unfamiliar and deserve to be discussed. There is for example, the northern branch of the inflow into the Sardinia Channel coming from west of Sardinia. Such a current contradicts Lacombe and Tchernia (1972), and Ovchinnikov (1966), but it agrees rather well with the observations of Garzoli and Maillard (1979) and the mod- els of Zavatarelli and Mellor (1995) and Roussenov et al. (1995). They show that in winter, northward flow west of Sardinia is due to cyclonic surface circulation between Sardinia and the Balearic Islands, while in summer, it is anticyclonic contributing to a secondary inflow into the Sardinia Channel. This branch is also visible in the model of Herbaut et al. (1998). Although our survey was in autumn, it obviously reproduces this feature. Closely related to this is the direction of flow in the channel. By contrast to the climatological studies of Lacombe and Tchernia $(1960,1972)$ and Ovchinnikov (1966) and the synoptic survey of Bouzinac et al. (1999), there is no indication for a westward vein close to the Sardinian coast. The flow direction more resembles the results of Garzoli and Maillard (1979) and Perkins and Pistek (1990). In the latter studies, the flow along the Algerian coast was westward, probably forced by a large anticyclonic eddy. Such an eddy was not found in the present survey, however, the anticyclonic meander of the Algerian Current at $8^{\circ} \mathrm{E}$ may be interpreted as a leftover of such a feature.

The meridional extent of the recirculation path in the Tyrrhenian varies seasonally (Krivosheya and Ovchinnikov, 1973; Krivosheya, 1983; Pierini and Simioli, 1998). In winter, the surface circulation exhibits a basin-scale cyclonic gyre, whereas in summer the major recirculation is confined to south of about $40^{\circ} \mathrm{N}$. In satellite 


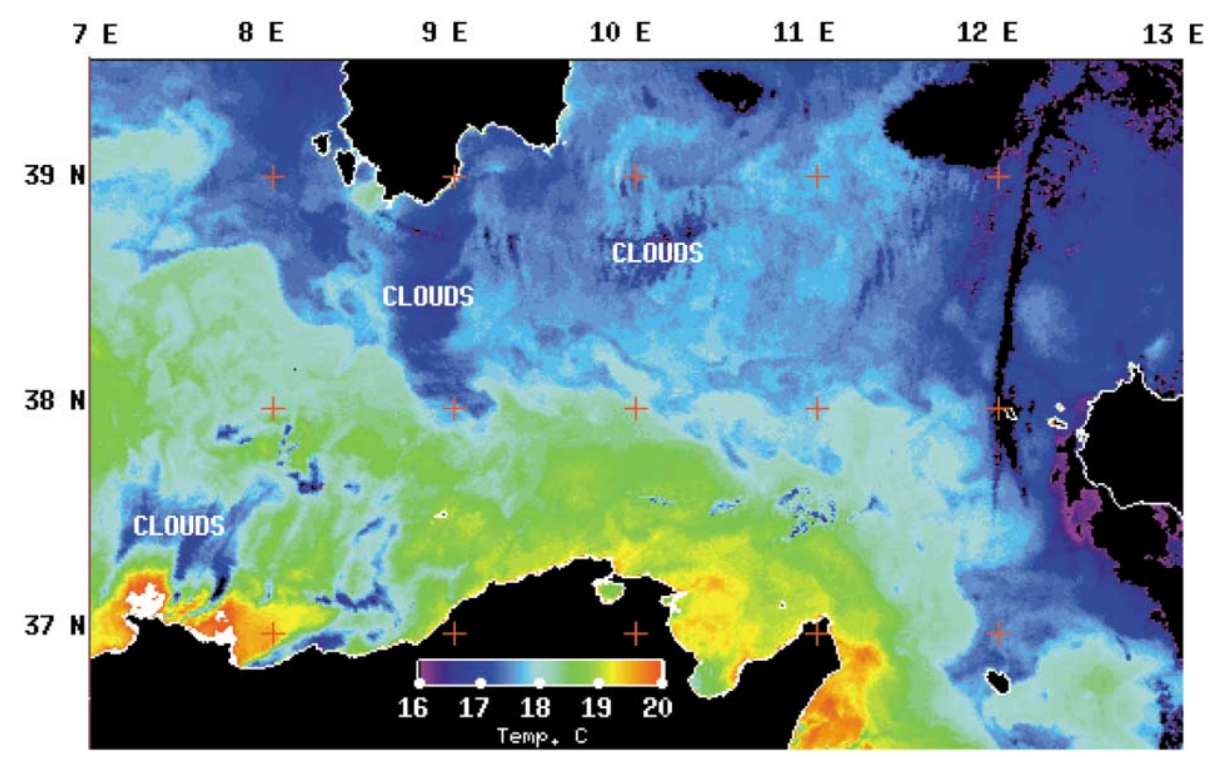

Figure 6. AVHRR infrared (channel 4) image of sea surface temperature, taken by the Tiros-N NOAA14 satellite on 29 October 1996 at $12 \mathrm{~h} 56$ UTC. Temperatures below $16^{\circ} \mathrm{C}$ are black, and above $20^{\circ} \mathrm{C}$ are white.

images, this becomes visible by a strong temperature front between Sardinia and Sicily (Marullo et al., 1994). In the present survey, the recirculation occurs via two paths; a well-defined tight recirculation cell is confined to south of $39^{\circ} \mathrm{N}$, and there is evidence for larger scale recirculation extending farther north. Hence, the October survey exhibits elements both of the summer and winter circulation. This transitional state is supported by figure 6 , which does not show any strong temperature front in the southern Tyrrhenian.

Both the Sardinia anticyclone and the Adventure Bank anticyclone are not verified by any climatological study, but there is indication from a few synoptic observations that they are recurrent features. The first was already identified by Krivosheya and Ovchinnikov (1973) as an "intense and stable" eddy, and a vein of MAW flow to the Tyrrhenian near the coast of Sardinia was observed by Garzoli and Maillard (1979). The Adventure Bank anticyclone was never mentioned before, but in conjunction with previous knowledge we conjecture that it is recurrent during summer. According to climatological observational studies and models, the flow in the Strait of Sicily occurs by means of a wide current extending over the entire width of the strait, with weak evidence of stronger flow on the Tunisian side. By synoptic observations, this pattern is partly confirmed, but only for winter. More often in summer, the flow was found to split into several branches; part of the outflow still hugs the Tunisian coast, but another significant fraction apparently occurs close to Sicily (Garzoli and Maillard, 1979; Manzella et al., 1988; Astraldi et al., 1996; Robinson et al., 1999). It is suggested that this vein is forced by the eastward branch of MAW after the flow splitting at $11^{\circ} \mathrm{E}$. When impinging on the west coast of Sicily, part of this becomes deflected to the south, thus stimulating anticyclonic circulation in this area. Furthermore, from Robinson et al. (1999) and Onken and Sellschopp (1998) it is known that a recurrent feature of the summer circulation is the Adventure Bank vortex, a cyclone that occupies the eastern slope of Adventure Bank. Hence, we conjecture that the enhanced southward flow part of the Adventure Bank anticyclone is partly forced by the Adventure Bank vortex.

Due to the smoothing of objective analysis, there is no evidence from figure 4 that the major topographic obstacles, Skerki Bank and Galite Bank, have any impact on the MAW flow path. By contrast, ADCP measurements clearly reveal a seaward deflection of the near surface flow by Galite Bank, but no deflection occurs over Skerki Bank. Probably, the depth and the shape of the topographic features are the reasons for this different behaviour. The horizontal extent and orientation of both obstacles is similar, but the region where the water depth is less than $100 \mathrm{~m}$ forms a connex area with Galite Bank, while the shallows of Skerki Bank are scattered. Hence, the dynamical impact of Galite Bank is similar to that of a seamount - it has to be circumvented anticyclonically. 
Skerki Bank is acting more like a seamount chain, where the fluid can pass through the gaps. This is in agreement with the distribution of the MAW salinity minimum in figure 3 (top), where the low salinity tongue is deflected north by Galite Bank, but is not hindered by Skerki Bank.

\subsection{Winter Intermediate Water}

In order to explore the distribution of WIW, all casts were scanned for a temperature minimum $T_{\min }$. The objectively analysed distribution of $T\left(T_{\min }\right)$ and $p\left(T_{\min }\right)$ (the tempera- ture and pressure of the minimum) in figure 7 reveal $T\left(T_{\min }\right)$ values $\leq 13.5^{\circ} \mathrm{C}$ southwest of a front extending from the northwest corner of the survey area to Galite Bank. Centred at about $38^{\circ} \mathrm{N}$, a cold tongue extends east as far as $12^{\circ} \mathrm{E}$. Opposed to this, a warm tongue is directed west, north of $38^{\circ} \mathrm{N}$. Provided that $T\left(T_{\min }\right)$ increases along the flow path, WIW obviously enters the survey region from the west, close to the Algerian coast. A secondary region of low $T\left(T_{\min }\right)$ is located east of Sardinia. Over the major part of the survey area, $p\left(T_{\min }\right)$ lies between 100 and $200 \mathrm{dbar}$. South of the front

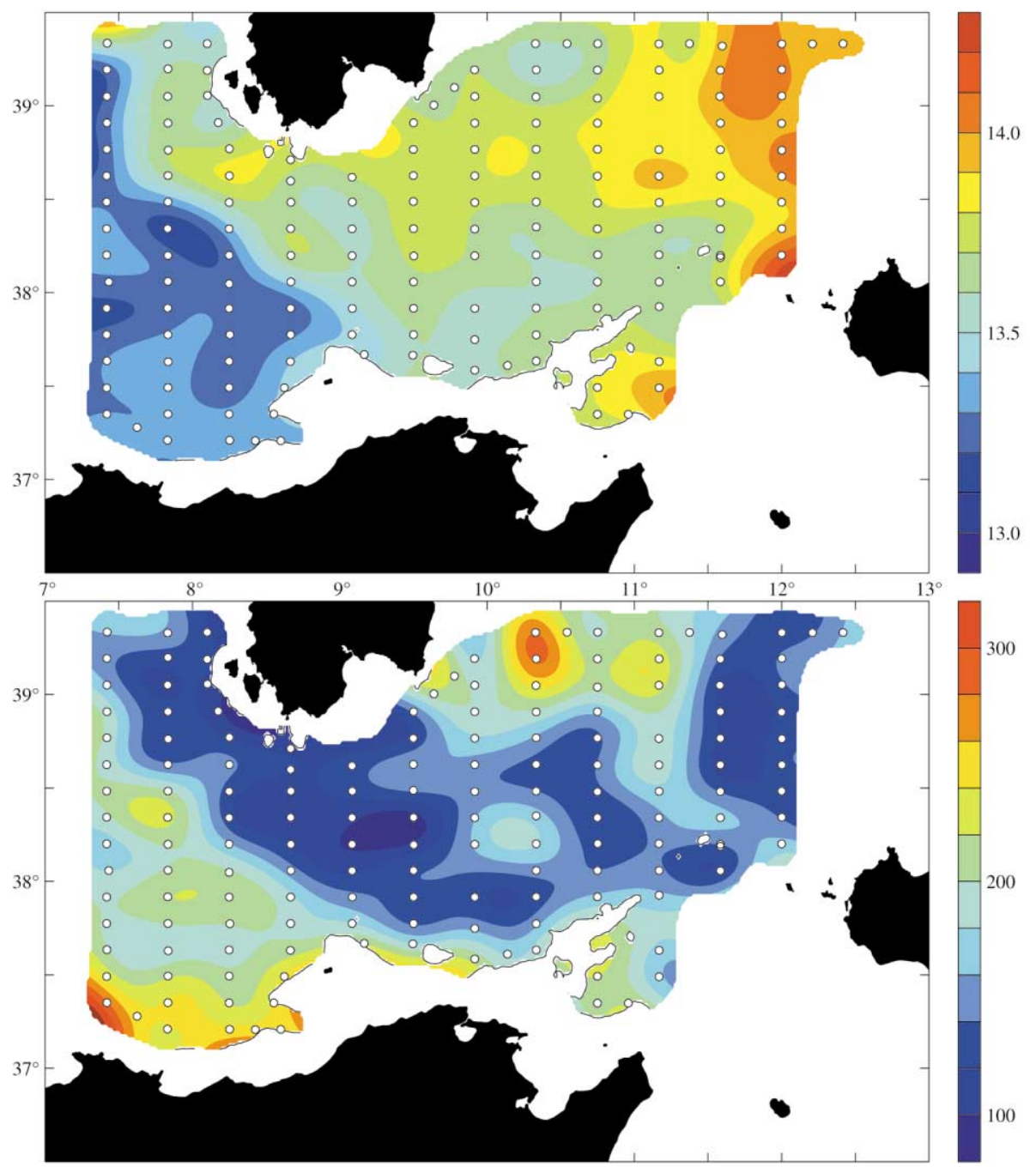

Figure 7. Objectively analysed temperature $T\left(T_{\min }\right)$ in degrees Celsius (top) and pressure $p\left(T_{\min }\right)$ in decibar (bottom) of the WIW temperature minimum. White dots indicate stations where a subsurface temperature minimum was found. Black solid lines denote the intersection of the $p\left(T_{\min }\right)$ surface with the bathymetry $H$. Areas where the root mean square error of the analysed fields is greater than $2 \varepsilon$ or $p\left(T_{\text {min }}\right)>H$ are left white. 
Figure 8. WIW mean geostrophic velocity assuming a level of no motion at 1000 dbar. For definition of the WIW layer see text. Only every fourth vector was plotted.

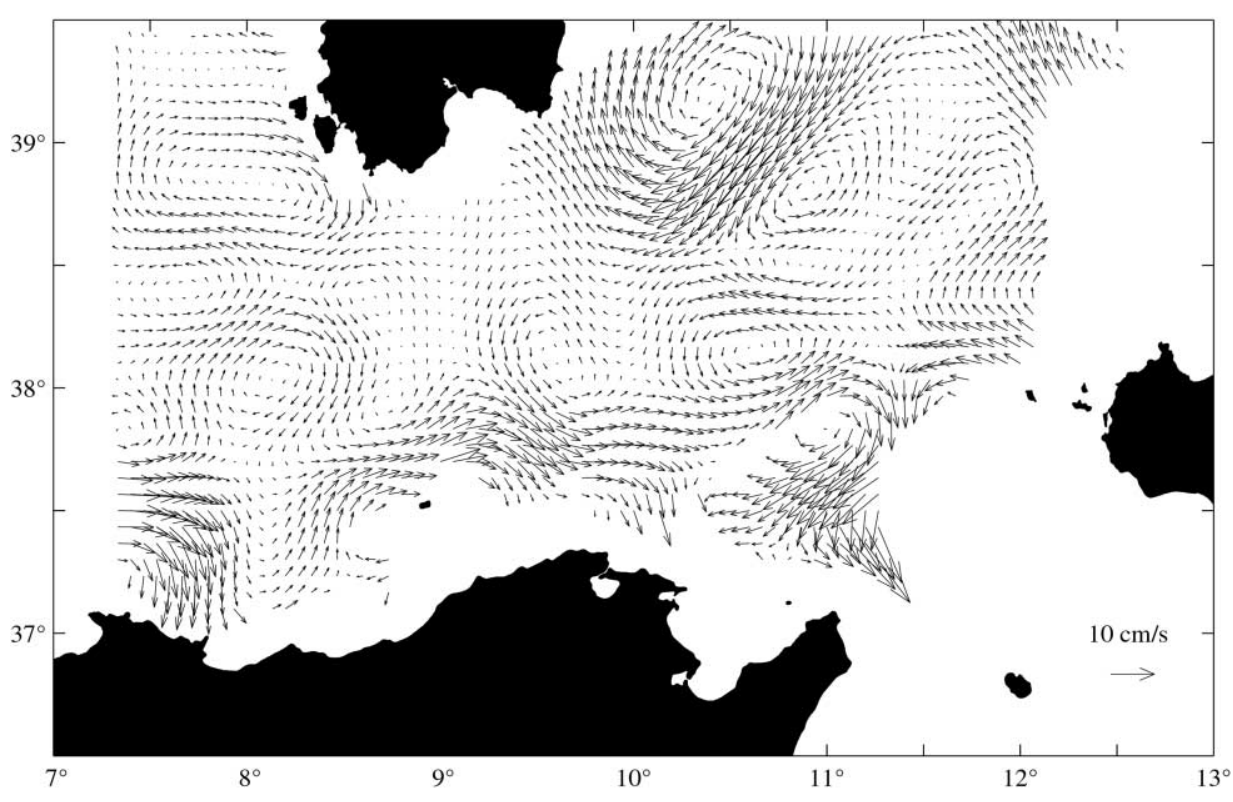

Sardinia Channel, WIW was everywhere encountered by Perkins and Pistek (1990). Essentially the same situation was described by Bouzinac et al. (1999), but they identified two veins on the Algerian and Sardinian side of the channel. Further evidence is gained from Katz (1972), who clearly found WIW between Sicily and Sardinia and in the Southern Tyrrhenian. All CTD sections across the Sardinia Channel described by Sammari et al. (1999) show $T_{\min }$ at about $170 \mathrm{~m}$ depth; similar values were encountered by Bouzinac et al. (1999). On our survey, $T_{\text {min }}$ lies shallower by several tens of metres, and Perkins and Pistek (1990) even found it between 200 and $400 \mathrm{~m}$. In addition, $T\left(T_{\min }\right)$ varies among the surveys by some tenths of a degree. Hence, the WIW location and characteristics seem to be variable, but we cannot decide yet whether this is due to interannual variability of WIW formation, seasonal variability, or simply a dynamical response to mesoscale processes. Alternatively, it has to be taken into account that WIW may be produced locally (Hopkins, 1988). Support is provided by Krivosheya (1983) suggesting another formation site in the Northern Tyrrhenian, and from climatological data bases (cf. Mediterranean Oceanic Data Base, 1999). The latter reveals that in the Western Tyrrhenian, the surface temperature may drop to $13^{\circ} \mathrm{C}$ in winter, which is similar to $T\left(T_{\min }\right)$ in figure 7.

In the western part of the Strait of Sicily, water with pronounced WIW characteristics was identified previ- 


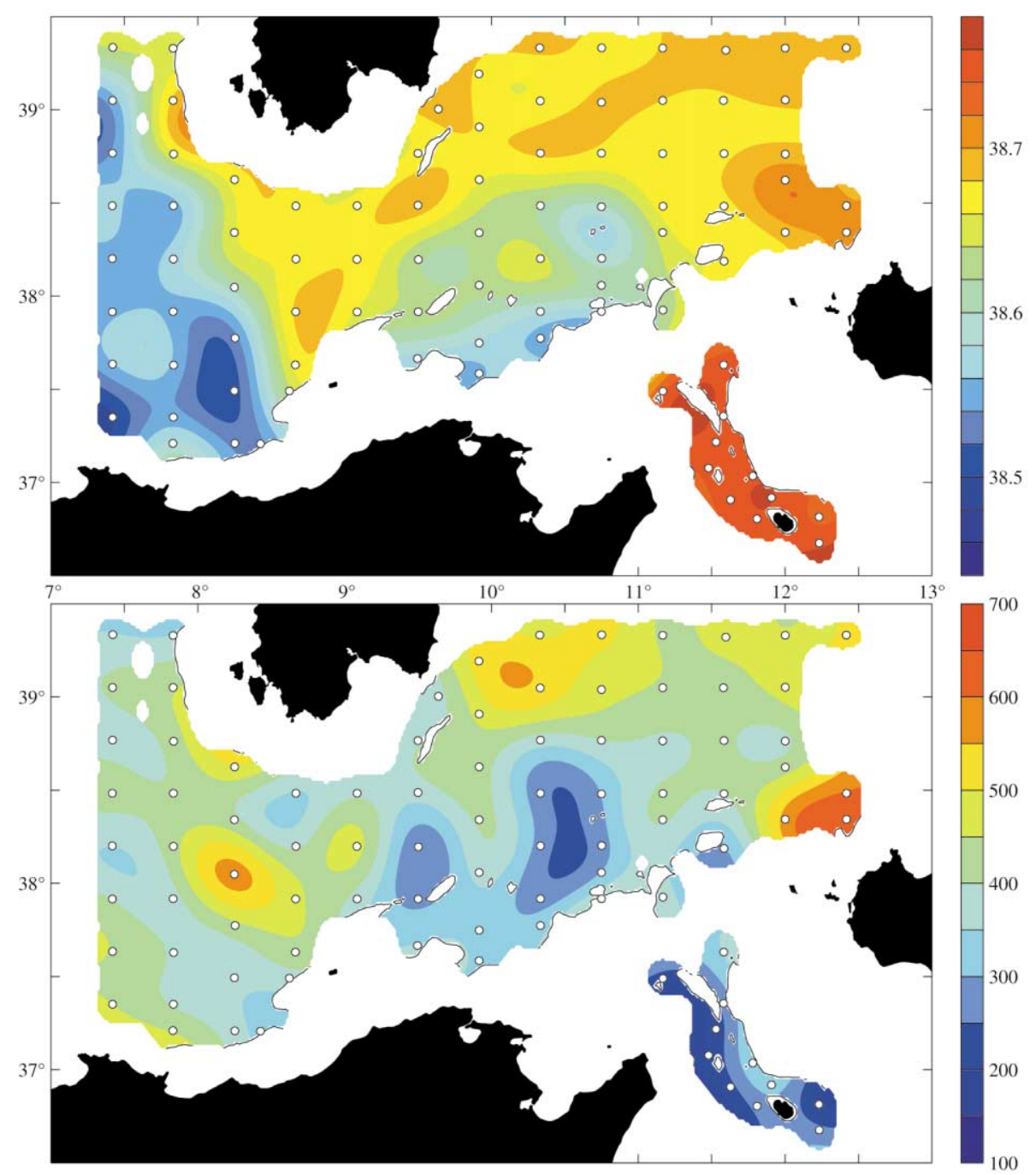

Figure 9. Objectively analysed salinity $S\left(S_{\max }\right)$ (top) and pressure $p\left(S_{\max }\right)$ in decibar (bottom) of the LIW salinity maximum. White dots indicate stations where a subsurface salinity maximum was found. Black solid lines denote the intersection of the $p\left(S_{\max }\right)$ surface with the bathymetry $H$. Areas where the root mean square error of the analysed fields is greater than $2 \varepsilon$ or $p\left(S_{\max }\right)>H$ are left white.

ously by Frassetto (1972), Molcard (1972), Shonting and Nacini (1972), Garzoli and Maillard (1979), and Astraldi et al. (1996), but only in winter and spring and never in summer or autumn. As also in our October survey we merely detected remnants of WIW in the strait, we hypothesize that the circulation undergoes a seasonal cycle; WIW enters the strait in winter/spring when the eastward MAW flow is strongest (Manzella, 1994) and is subsequently mixed in summer and autumn, thus losing its properties.

\subsection{Levantine Intermediate Water}

LIW is characterized by an absolute maximum of salinity at intermediate depth. The analysed distribution of $S\left(S_{\max }\right)$ and $p\left(S_{\max }\right)$ (the salinity and pressure of the maximum) are shown in figure 9. Provided that $S\left(S_{\max }\right)$ decreases along the main path, figure 9 suggests LIW to enter the survey region via the Strait of Sicily, where the highest $S\left(S_{\max }\right)$ values (close to 38.8) are found near Pantelleria. Towards the northwest, $S\left(S_{\max }\right)$ decreases 
rapidly by about 0.1 when approaching Skerki Bank indicating strong vertical mixing. Further evidence for strong mixing is gained from the fact that there is no intermediate $S_{\max }$ between the exit of the Strait of Sicily and the Tyrrhenian. From the Eastern Tyrrhenian, a high salinity tongue $38.66 \leq S\left(S_{\max }\right) \leq 38.72$ is directed west towards Sardinia. A flow splitting occurs obviously in the Sardinia Channel, where one high salinity tongue is attached to the west Sardinian shelf and another extends south towards Galite Bank. Hence, the large scale circulation in the Sardinia/Tunisia/Sicily region seems to be cyclonic. Between Galite Bank and Skerki Bank, $S\left(S_{\max }\right)$ lies below 38.66, the lowest values of $<38.54$ being found close the Tunisian shelf. West of the Sardinia Channel, a strong front extends from Galite Bank to the northwest corner of the survey area, separating old LIW in the west from younger in the east. The $p\left(S_{\max }\right)$ distribution is rather patchy. Low values between 200 and $300 \mathrm{dbar}$ are encountered in the Strait of Sicily and between Galite Bank and Skerki Bank. Values between 300 and 600 dbar are attained in the southern Tyrrhenian and west of $9^{\circ} \mathrm{E}$, while the absolute maximum exceeding $600 \mathrm{dbar}$ is attained northwest off Sicily, supporting the finding of Sparnocchia et al. (1999), that at least part of the LIW cascades to great depth in the Tyrrhenian Sea.

The geostrophic velocity, averaged between the lower boundary of WIW and 1000 dbar (figure 10), exhibits maximum speeds of close to $10 \mathrm{~cm} \mathrm{~s}^{-1}$ in the Strait of Sicily north of Cape Bon. East of the cape, the velocity is westward and the vectors are approximately parallel to the bathymetry contours. Between Skerki Bank and Adventure Bank, the flow direction is mainly west/southwest. A northward component is only found close to Adventure Bank. A flow separation occurs at about $\left(12^{\circ} \mathrm{E}, 38.5^{\circ} \mathrm{N}\right)$ : one branch goes north and appears to perform a large-scale cyclonic loop in the southern Tyrrhenian; the other branch circumvents Skerki Bank and proceeds west. A further separation occurs southeast of Sardinia. The northern fraction of LIW recirculating from the Tyrrhenian is entrained in the Sardinia anticyclone, the southern part is directed southwest to the Tunisian coast, and the central fraction proceeds west into the Sardinia Channel and circumvents Sardinia anticyclonically. In the west, the major inflow into the survey region occurs at about $37^{\circ} 30^{\prime} \mathrm{N}$. One fraction of this is running towards the Algerian shelf, and the other recirculates cyclonically and joins the anticyclonic flow around Sardinia.

All along the Algerian/Tunisian shelf and on the western side of Adventure Bank, the flow exhibits a component normal to bathymetry contours. It has been verified that this unexpected behaviour is neither due to selection of a wrong level of no motion, nor to vertical averaging. Hence, we speculate that there are either narrow along-
Figure 10. LIW mean geostrophic velocity assuming a level of no motion at 1000 dbar. For definition of the LIW layer see text. Only every fourth vector was plotted

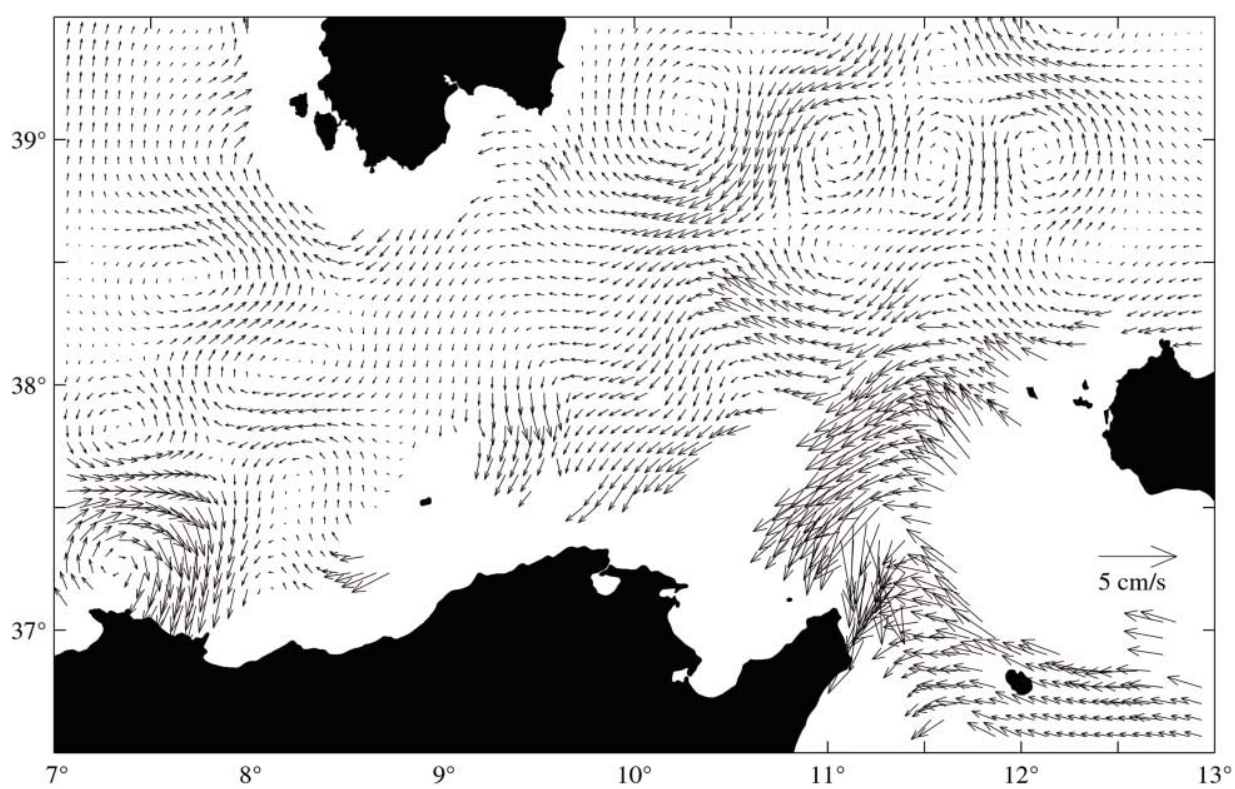




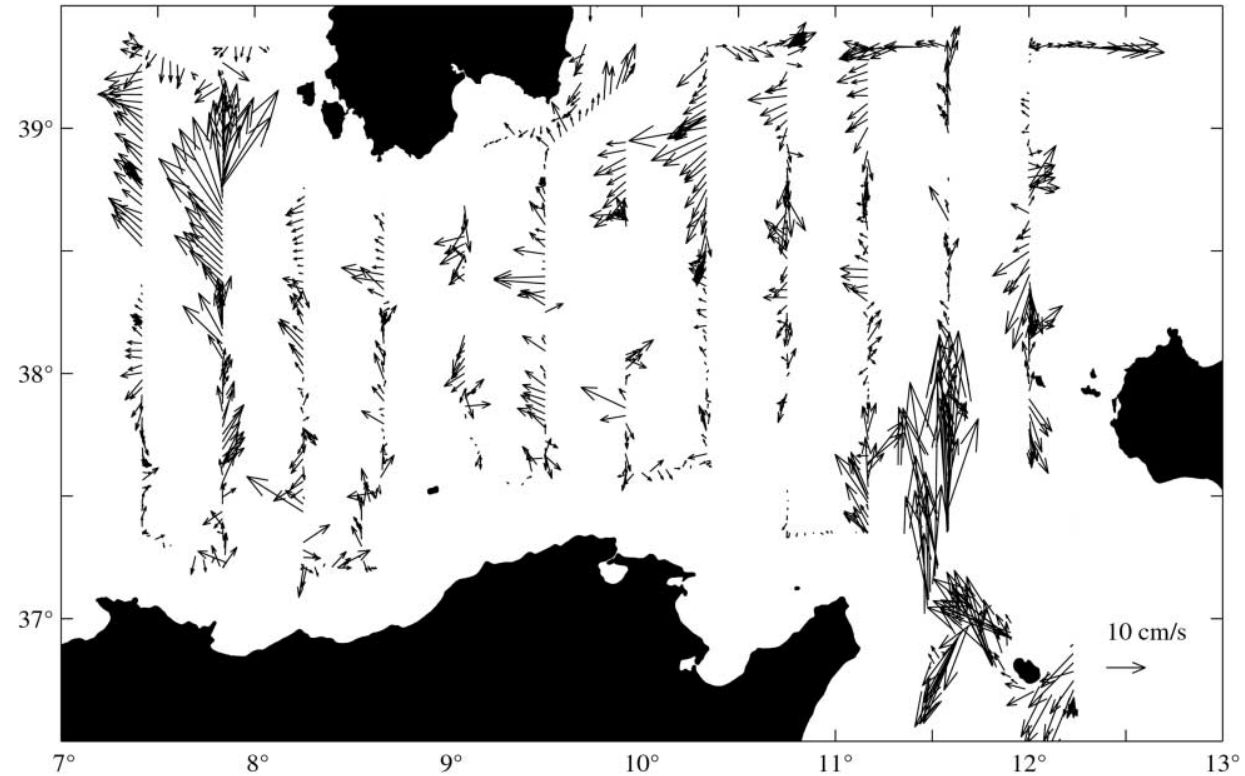

Figure 11. Currents directly measured from ship-borne ADCP, averaged over the vertical range 202-450 m. Each vector represents a $10 \mathrm{~min}$ ensemble average. shelf geostrophic boundary currents, which are not properly resolved by the measurements, or the boundary currents are strongly affected by ageostrophic effects, i.e. friction. It was also attempted to validate the LIW geostrophic currents by ADCP measurements, although the data quality was already very low in the respective depth range. Nevertheless, if one disregards the smallscale noisy features and makes only a qualitative comparison, figure 11 contains a number of consistent (i.e. visible on different ship tracks) patterns, which approximately match the geostrophic currents. This is the westward flow band in the Southern Tyrrhenian, the Sardinia anticyclone, the anticyclonic flow around Sardinia, and the tendency of westward flow between Skerki Bank and Galite Bank. It is also remarkable that the ADCP currents do not show a continuous flow between Skerki Bank and Adventure Bank to the Tyrrhenian. Hence, there are good reasons to trust the geostrophic calculations.

There is evidence for a direct vein of LIW extending west from the Strait of Sicily, but this vein is only partly manifest in the $S\left(S_{\max }\right)$ distribution. Otherwise, the flow pattern resembles more the findings of Ovchinnikov (1966), Krivosheya and Ovchinnikov (1973), Krivosheya (1983), Hopkins (1988), and Manzella et al. (1988). It is suggested that a direct vein may be generated only under the influence of special conditions. In the northern Sardinia Channel, westward flow is in agreement with earlier publications, but a coherent jet-like band attached to the shelf slope is missing. In the present case such a band is apparently interrupted by the Sardinia anticyclone absorbing a significant fraction of the LIW coming from the Tyrrhenian. In the southern Sardinia Channel, previous findings are controversial. Perkins and Pistek (1990) and Garzoli and Maillard (1979) found westward flow, while Bouzinac et al. (1999) reported on eastward current direction. In a similar way, the flow west of the channel is still under debate. There is no disagreement that the LIW confined to the southern slope of Sardinia turns anticyclonically around the island, but according to Ovchinnikov (1966) and models (Wu and Haines, 1996) another vein separates from that LIW right off the southern tip of Sardinia and proceeds southwest to the Algerian coast. In the present observations, this vein is missing, but the northward flow along the Sardinian west coast is well reproduced. Probably, the variability of LIW flow at the western entrance of the channel is caused by sporadic advection of anticyclonic eddies of the Algerian Current (Millot, 1985).

In order to address the question of the origin of the low $S\left(S_{\max }\right)$ patch between Galite Bank and Skerki Bank, figure 12 displays the structure of potential temperature and salinity in different regimes of the survey area. For discrimination between different LIW regimes, the casts were separated in four classes according to location and $S\left(S_{\max }\right)$ (table I). Figure 12 reveals that above 250 dbar, Skerki LIW exhibits almost the same characteristics as 

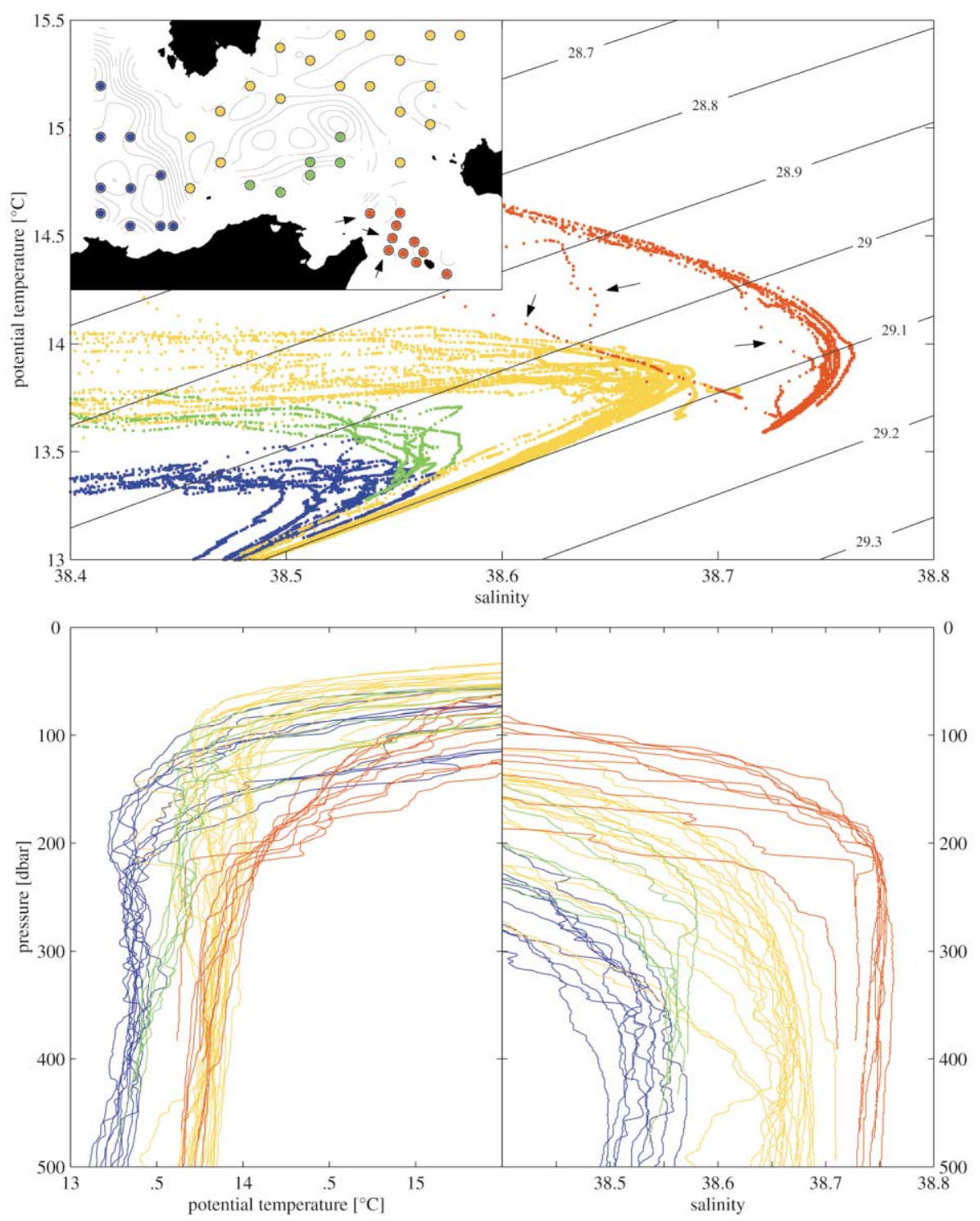

Figure 12. Top: $T / S$ diagram of the LIW range for different regimes of the survey area. Contours refer to potential density anomaly $\sigma_{\mathrm{o}}\left[\mathrm{kg} \mathrm{m}^{-3}\right]$. The colour coding matches the colour of the circles in the inset map indicating the positions of CTD stations. Contour lines in the inset map are identical to those in figure 9Arrows in the T/S graph and in the inset map are marking those stations in the Strait of Sicily where LIW of Tyrrhenian origin was found. Bottom: Profiles of potential temperature in degrees (left) and salinity (right) of the top 500 dbar corresponding to the $T / S$ graphs above.

Tyrrhenian LIW, whereas below $350 \mathrm{dbar}$, it is almost identical with Algerian LIW, which had apparently invaded the Skerki region from the west and later became detached by the southward migrating Tyrrhenian LIW in the Sardinia Channel. Below 350 dbar, the advection of Algerian LIW involved a freshening and cooling and simultaneously a freshening and upward migration of the salinity maximum. The latter is visible from figure 9 (bottom) and the $T / S$ diagram of figure 12. These findings agree with Sammari et al. (1999), who concluded that old LIW from the Algerian Basin proceeds east along the Tunisian slope up to the western exit of the Strait of Sicily, where it meets young LIW from the Eastern Mediterranean. 
Table I. LIW regimes in the survey region.

\begin{tabular}{llll}
\hline LIW class & Location & Salinity range & Colour coding \\
\hline Algerian & West of Sardinia Channel & $S\left(S_{\max }\right) \leq 38.58$ & blue \\
Skerki & Between Galite and Skerki banks & $S\left(S_{\max }\right) \leq 38.60$ & green \\
Strait of Sicily & Strait of Sicily & $38.74 \leq S\left(S_{\max }\right)$ & red \\
Tyrrhenian & Entire survey region & $38.66 \leq S\left(S_{\max }\right) \leq 38.70$ & orange \\
\hline
\end{tabular}

$S\left(S_{\max }\right)$ is the salinity of the LIW salinity maximum. The colour coding refers to figure 12 .

Figure 12 reveals in addition, important information on the LIW circulation in the Strait of Sicily. The $T / S$ curves of seven out of ten CTD casts containing Strait of Sicily LIW are almost identical. The other three curves (marked by arrows), however, differ considerably; both temperature and salinity are lower and exhibit partly the characteristics of Tyrrhenian LIW and WIW (see above). As the corresponding CTD casts are all located on the Tunisian side of the strait, it is concluded that a fraction of the Strait of Sicily LIW mixes with Tyrrhenian LIW and WIW in the Skerki Bank area, and recirculates cyclonically in the strait. Evidence for such recirculation was already gained from figure 10.

\section{CONCLUSION}

For the first time, during autumn 1996, a consistent pattern of the water mass distribution and circulation between the Eastern Algerian Basin and the Strait of Sicily has been obtained from a high-resolution oceanographic survey. The distribution of MAW, WIW and LIW were diagnosed by the core method and the velocity field was determined in terms of geostrophic currents and validated to a large extent by direct measurements.

Between the Sardinia Channel and the Strait of Sicily, the large-scale flow of MAW and WIW is cyclonic. The cyclonic gyre is fed by eastward flow in the southern Sardinia Channel, and by some contribution coming from the northern Tyrrhenian Sea. MAW and WIW leave the cyclonic circulation via the Strait of Sicily. Outflow to the Tyrrhenian is accomplished northwest of Sicily and close to the Sardinian coast. The LIW pattern resembles that of the overlying MAW/WIW only north of a line between Sicily and Sardinia. In the Strait of Sicily the LIW flow is opposed. There is evidence that LIW from the Algerian Basin proceeds east along the Tunisian slope up to the western exit of the Strait of Sicily.
In the Eastern Algerian Basin the flow of all water masses is to the east, close to the Algerian shelf. Farther offshore, MAW flows mainly southwest contributing to additional inflow into the Sardinia Channel, while the LIW is opposed to that supporting northward transport along the Sardinian shelf. No prevailing direction could be diagnosed for WIW.

In the Sardinia Channel, the MAW flow is mainly eastward. In the WIW range, eastward flow prevails only along the Algerian/Tunisian shelf, whereas the WIW in the northern half of the channel goes west. The alongchannel exchange of LIW appears to be confined to a narrow band of westward flow on the Sardinian shelf slope.

Mesoscale features were found to have an important impact on the general circulation. The most prominent examples are an intense anticyclone east of Sardinia preventing continuous flow from the Tyrrhenian Sea to the Algerian Basin at all levels, and another anticyclonic eddy between Sicily and Cape Bon supporting a secondary vein of MAW outflow into the Strait of Sicily close to the Sicilian coast. Cyclonic motion in the Sardinia Channel is dragging parts of WIW and LIW from the Sardinian to the Tunisian coast. The circulation and water mass distribution is influenced by topographic obstacles, namely Galite Bank and Skerki Bank.

All findings of this paper are based on the analysis of a single quasi-synoptic data set collected in October 1996. The situation described is only representative for this month of that particular year and it is not claimed that it represents any 'mean' or 'autumn' situation of this region. In order to find out to what extent the situation might represent mean conditions, it should be compared with climatological data sets. This may be the subject of another study. 


\section{Acknowledgements}

This work was performed at the SACLANT Undersea Research Centre in La Spezia, Italy. We would like to thank the crew of NRV Alliance and our technical staff for acquisition of the data. The ADCP data were processed by G. Baldasserini, and A. Legner helped with the graphics. The satellite image was kindly provided by E. Nacini and the French translation of the abstract by E. Pouliquen.

\section{REFERENCES}

Astraldi, M., Gasparini, G.P., 1994. The seasonal characteristics of the circulation in the Tyrrhenian Sea. In: La Violette, P.E. (Ed.), The seasonal and interannual variability of the Western Mediterranean sea, Coastal and Estuarine Studies. Amer. Geophys. Union 46, 115-134.

Astraldi, M., Gasparini, G.P., Sparnocchia, S., Moretti, M., Sansone, E., 1996. The characteristics of the water masses and the water transport in the Sicily Strait at long time scales. Bull. Inst. Océanogr., Monaco, $\mathrm{n}^{\circ}$ spécial 17, 95-117.

Bethoux, J.P., 1980. Mean water fluxes across sections in the Mediterranean Sea, evaluated on the basis of water and salt budgets and of observed salinities. Oceanol. Acta 3, 79-88.

Bouzinac, C., Font, J., Millot, C., 1999. Hydrology and currents observed in the Channel of Sardinia during the PRIMO-1 experiment from November 1993 to October 1994. J. Mar. Syst. 20, 333-355.

Carter, E.F., Robinson, A.R., 1987. Analysis models for the estimation of oceanic fields. J. Atmosph. Ocean. Technol. 4, 49-74.

Frassetto, R., 1972. A study of the turbulent flow and character of the water masses over the Sicilian Ridge in both summer and winter, SACLANTCEN conference proceedings, no. 7. SACLANT ASW Research Centre, La Spezia, pp. 38-44.

Garzoli, S., Maillard, C., 1979. Winter circulation in the Sicily and Sardinia Strait region. Deep-Sea Res. 26, 933-954.

Herbaut, C., Codron, F., Crépon, M., 1998. Separation of a coastal current at a Strait level: case of the Strait of Sicily. J. Phys. Oceanogr. 28, 1346-1362.

Hopkins, T.S., 1988. Recent observations on the intermediate and deep water circulation in the Southern Tyrrhenian Sea. In: Minas, H.J., Nival, P. (Eds.), Océanographie pélagique méditerraneénne. Oceanol. Acta, 12 (special issue no 9), pp. 41-50.

Katz, E.J., 1972. The Levantine Intermediate Water between the Strait of Sicily and the Strait of Gibraltar. Deep-Sea Res. 19, 507-520.

Krivosheya, V.G., 1983. Water circulation and structure in the Tyrrhenian Sea. Oceanology 23, 166-171.

Krivosheya, V.G., Ovchinnikov, I.M., 1973. Peculiarities in the geostrophic circulation of the waters of the Tyrrhenian Sea. Oceanology $13,822-827$.
Lacombe, H., Tchernia, P., 1960. Quelques traits généraux de l'hydrologie Méditerranéenne. Cah. Océanogr. 12, 527-547.

Lacombe, H., Tchernia, P., 1972. Caractères hydrologiques et circulation des eaux en Méditerranée. In: Stanley, D.J. (Ed.), The Mediterranean Sea. Dowden, Hutchinson and Ross, Inc., Stroudsbourg, PA, pp. 26-36.

Manzella, G.M.R., 1994. The seasonal variability of the water masses and transport through the Strait of Sicily. In: La Violette, P.E. (Ed.), The seasonal and interannual variability of the Western Mediterranean Sea, Coastal and Estuarine studies. Amer. Geophys. Union 46, $33-45$.

Manzella, G.M.R., Gasparini, G.P., Astraldi, M., 1988. Water exchange between the eastern and western Mediterranean through the Strait of Sicily. Deep-Sea Res 35, 1021-1035.

Marullo, S., Santoleri, R., Bignami, F., 1994. The surface characteristics of the Tyrrhenian Sea: historical satellite data analysis. In: La Violette, P.E. (Ed.), The seasonal and interannual variability of the Western Mediterranean Sea, Coastal and Estuarine studies. Amer. Geophys. Union, 46, 135-154.

Mediterranean Oceanic Data Base, 1999. http://modb.oce.ulg.ac.be.

Millot, C., 1985. Some features of the Algerian Current. J. Geophys. Res. 90, 7169-7176.

Millot, C., 1999. Circulation in the Western Mediterranean Sea. J. Mar. Syst. 20, 424-442.

Molcard, R., 1972. Preliminary results of current measurements in the Strait of Sicily in May 1970, SACLANTCEN conference proceedings no. 7. SACLANT ASW Research Centre, La Spezia, pp. $82-95$.

Ovchinnikov, I.M., 1966. Circulation in the surface and intermediate layers of the Mediterranean. Oceanology 6, 48-59.

Onken, R., Sellschopp, J., 1998. Seasonal variability of flow instabilities in the Strait of Sicily. J. Geophys. Res. 103, 24799-24820.

Perkins, H., Pistek, P., 1990. Circulation in the Algerian Basin during June 1986. J. Geophys. Res. 95, 1577-1585.

Pierini, S., Simioli, A., 1998. A wind-driven circulation model of the Tyrrhenian Sea area. J. Mar. Syst. 18, 161-178.

Robinson, A.R., Sellschopp, J., Warn-Varnas, A., Leslie, W.G., Lozano, C.J., Haley, P.J. Jr., Anderson, L.A., Lermusiaux, P.F.J., 1999. The Atlantic Ionian Stream. J. Mar. Syst. 20, 129-156.

Roussenov, V., Stanev, E., Artale, V., Pinardi, N., 1995. A seasonal model of the Mediterranean Sea general circulation. J. Geophys. Res. 100, 13515-13538.

Salat, J., Font, J., 1987. Water mass structure near and offshore the Catalan coast during the winter of 1982 and 1983. Ann. Geophys. 1, $49-54$.

Sammari, C., Millot, C., Taupier-Letage, I., Stefani, A., Brahmi, M., 1999. Hydrological characteristics in the Tunisia-Sardinia-Sicily area during spring 1995. Deep-Sea Res. I, 46, 1671-1703. 
Shonting, D.H., Nacini, E., 1972. A summary of oceanographic data obtained in deep water in the Strait of Sicily in May 1970, SACLANTCEN conference proceedings no. 7. SACLANT ASW Research Centre, La Spezia, pp. 45-67.

Sparnocchia, S., Gasparini, G.P., Astraldi, M., Borghini, M., Pistek, P., 1999. Dynamics and mixing of the Eastern Mediterranean outflow in the Tyrrhenian basin. J. Mar. Syst. 20, 301-317.
Wu, P., Haines, K., 1996. Modeling the dispersal of Levantine Intermediate Water and its role in Mediterranean deep water formation. J. Geophys. Res. 101, 6591-6607.

Wüst, G., 1961. On the vertical circulation of the Mediterranean Sea. J. Geophys. Res. 66, 3261-3271.

Zavatarelli, M., Mellor, G.L., 1995. A numerical study of the Mediterranean Sea circulation. J. Phys. Oceanogr. 25, 1384-1414. 